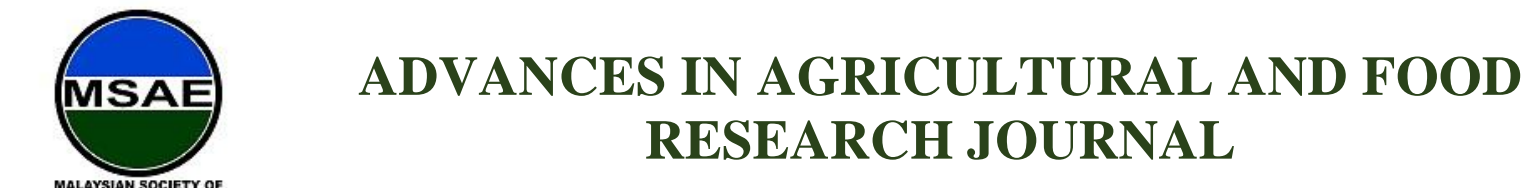

Review Article

\title{
Dabai Fruit: Postharvest Handling and Storage
}

Siti Hajar Ariffin ${ }^{1,2^{*}}$, Rosnah Shamsudin ${ }^{1,2}$, Intan Syafinaz Mohamed Amin Tawakkal ${ }^{1,2}$

${ }^{1}$ Department of Process and Food Engineering, Faculty of Engineering, Universiti Putra Malaysia, 43400, Serdang, Selangor, Malaysia

${ }^{2}$ Laboratory of Halal Services, Halal Products Research Institute, Universiti Putra Malaysia, 43400, Serdang, Selangor, Malaysia

*Corresponding author: Siti Hajar Ariffin, Department of Process and Food Engineering, Faculty of Engineering, Universiti Putra Malaysia, 43400, Serdang, Selangor, Malaysia; hajarariffin@upm.edu.my

Abstract: Dabai (Canarium odontophyllum) or also known as 'Sarawak olive' is one of the potential indigenous seasonal fruits commonly found in Sarawak. Due to its high nutritional contents, it has wide potential to be marketed locally and exported internationally. Dabai is very delicate and highly perishable. The shelf life of dabai is usually 3 days when stored in room temperature $\left(27^{\circ} \mathrm{C}\right)$. Improper storage and handling lead to the reduction of quality and shelf life of the fruit throughout storage. There is still a limitation on the information of postharvest, storage and handling, quality and shelf life of dabai. Studies on quality and shelf life affected by storage treatment and packaging are necessary for optimising shelf life and minimising quality loss of the fruit. This could ensure further potential development of the fruit locally and internationally.

Keywords: Dabai; Canarium odontophyllum; Sarawak olive; nutritional values; harvesting, storage; handling

Received: $13^{\text {rd }}$ September 2020

Accepted: $14^{\text {th }}$ October 2020

Available Online: $31^{\text {st }}$ October 2020

Citation: Ariffin SH, Shamsudin R \& Tawakkal ISMA. Dabai Fruit: Postharvest handling and storage. Adv Agri Food Res J 2020; 1(2): a0000126. https://doi.org/10.36877/aafrj.a0000126

\section{Introduction}

\subsection{Origin}

Dabai (Canarium odontophyllum) which is also known as 'Sarawak olive' is an indigenous seasonal fruit that can only be found in Borneo Island, especially Sarawak. In Malaysia, the medium-sized tree grows naturally along river banks in Sarikei, Limbang, Sibu, 
and Kapit (Ding, 2011). The tree grows upright up to $21 \mathrm{~m}$ high and has thin, large pinnate leaves. Fresh leaves form in red velvet or green colour. Branchlets have resinous ducts and petioles. The flower is $10 \mathrm{~mm}$ long and is white-yellow (see Figure 1). Depending on the local weather, dabai usually available from May till June and December till January every year (Chua \& Daniel, 2017).
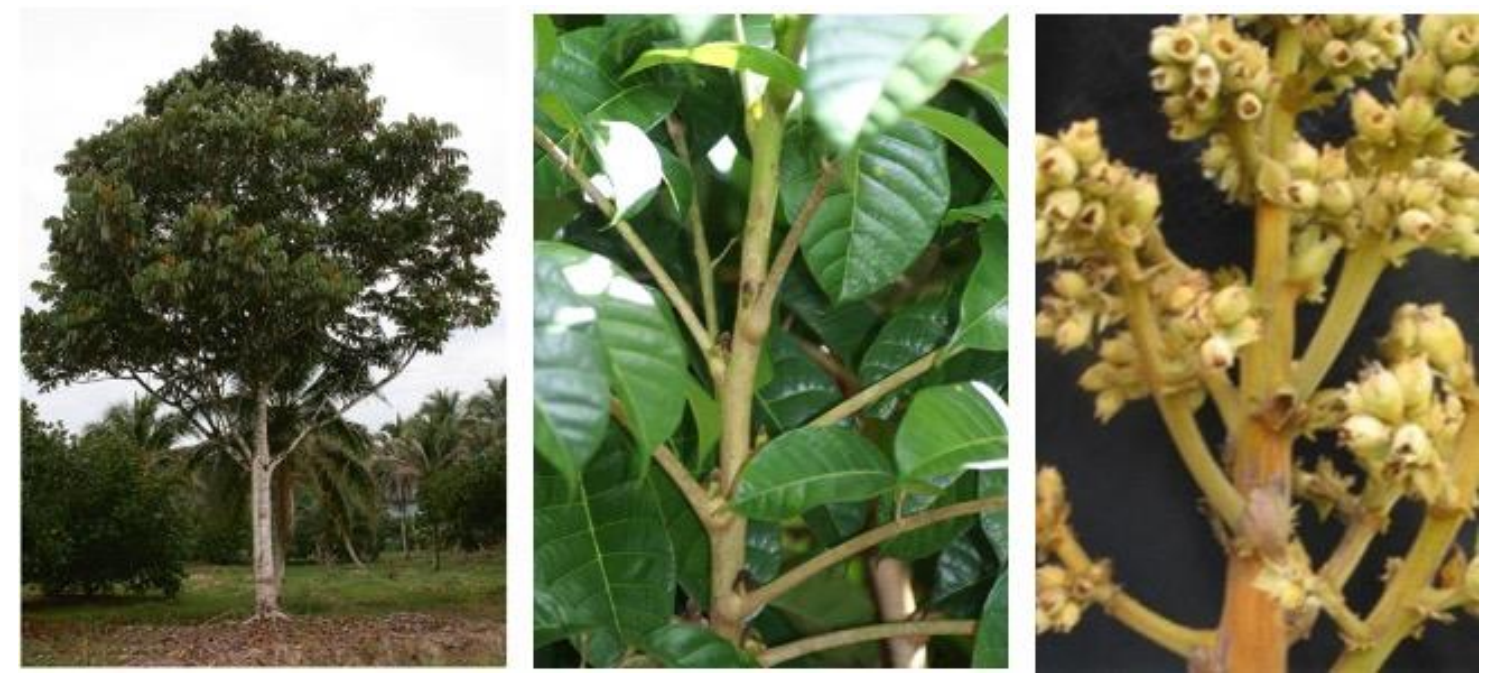

Figure 1. From left, dabai tree, dabai stem and leaves (HealthBenefits) and dabai flowers (Cangao, 2014).

Dabai has bright potential to be economic crop in the state. Being a popular indigenous fruit in Sarawak, it has wide potential to be marketed locally and exported internationally. Among all states in Malaysia, with 38 varieties of fruits, plantation of dabai covered the highest hectarage with $1,439.40$ ha. That contributes to $26 \%$ of total hectarage for plantation of fruit crops in Malaysia (Table 1) (Department of Agriculture Malaysia, 2017). 
Table 1. Hectarage of fruit crops by state and type in Malaysia (Department of Agriculture Malaysia, 2017).

\begin{tabular}{|l|r|}
\hline \multicolumn{1}{|c|}{$\begin{array}{c}\text { NEGERI } \\
\text { State }\end{array}$} & \multicolumn{1}{c|}{$\begin{array}{c}\text { Keluasan } \\
\text { Hectareage } \\
\text { (Ha) }\end{array}$} \\
\hline JOHOR & 903.8 \\
\hline KEDAH & 132.7 \\
\hline KELANTAN & 363.4 \\
\hline MELAKA & 328.4 \\
\hline NEGERI SEMBILAN & 161.3 \\
\hline PAHANG & 462.1 \\
\hline PERAK & 100.8 \\
\hline PERLIS & 17.0 \\
\hline PULAU PINANG & 5.7 \\
\hline SELANGOR & 96.8 \\
\hline TERENGGANU & 93.8 \\
\hline $\begin{array}{l}\text { SEM. MALAYSIA } \\
\text { Peninsular Malaysia }\end{array}$ & $\mathbf{2 , 6 6 5 . 6}$ \\
\hline $\begin{array}{l}\text { SABAH } \\
\text { SARAWAK } \\
\text { W.P. LABUAN }\end{array}$ & $\mathbf{7 2 2 . 3}$ \\
\hline $\begin{array}{l}\text { MALAYSIA TIMUR } \\
\text { East Malaysia }\end{array}$ & $2,11.5$ \\
\hline MALAYSIA & 2.1 \\
\hline
\end{tabular}

\begin{tabular}{|ll|r|}
\hline \multicolumn{2}{|c|}{$\begin{array}{c}\text { Jenis Buah } \\
\text { Type of Fruits }\end{array}$} & $\begin{array}{c}\text { Keluasan } \\
\text { Hectareage } \\
\text { (Ha) }\end{array}$ \\
\hline Abui & Pouteria & - \\
\hline Anggur & Grape & 0.40 \\
\hline Avocado & Avocado & 41.70 \\
\hline Bacang & Horse Mango & 68.02 \\
\hline Bambangan & (Bambangan) & 27.80 \\
\hline Belunu & (Belunu) & 7.80 \\
\hline Belimbing Buluh & (Belimbing Buluh) & 41.44 \\
\hline Belimbing Hutan & (Belimbing Hutan) & 0.01 \\
\hline Bidara Siam & Jujube & - \\
\hline Berangan & (Berangan) & 7.00 \\
\hline Buah Ajaib & Miracle Fruit & - \\
\hline Dabai & (Dabai) & $1,439.40$ \\
\hline Durian Belanda & Sour-sop & 443.99 \\
\hline Gajus & Cashew & 1.69 \\
\hline Jambu Air & Water Rose Apple & 404.35 \\
\hline Jambu Air Mawar & Water Rose Apple & 27.51 \\
\hline Kabung/Enau & (Kabung/Enau) & 16.00 \\
\hline Kedondong / Amra & (Kedondong/Amra) & 50.28 \\
\hline Kelubi & (Kelubi) & 0.44 \\
\hline Keranji & (Keranji) & - \\
\hline Kundang & (Kundang) & 1.38 \\
\hline
\end{tabular}

\begin{tabular}{|ll|r|}
\hline \multicolumn{2}{|c|}{$\begin{array}{c}\text { Jenis Buah } \\
\text { Type of Fruits }\end{array}$} & $\begin{array}{c}\text { Keluasan } \\
\text { Hectareage } \\
\text { (Ha) }\end{array}$ \\
\hline Kuini & (Kuini) & 930.63 \\
\hline Lemon & (Lemon) & 46.00 \\
\hline Longan & (Longan) & 92.49 \\
\hline Markisa & Passion Fruit & 72.60 \\
\hline Mata Kucing & Cat's Eye & 103.67 \\
\hline Mentega & (Mentega) & 0.90 \\
\hline Mesta & (Mesta) & 28.48 \\
\hline Nona Kapri & Custard Apple & 3.00 \\
\hline Nona Srikaya & Sweet-sop & 1.60 \\
\hline Pisang Kaki & Diospryros & 13.70 \\
\hline Rambai & (Rambai) & 60.17 \\
\hline Sentol & (Sentol) & 2.87 \\
\hline Strawberi & Strawberry & 38.61 \\
\hline Sukun & Breadfruit & 54.72 \\
\hline Tarap & (Tarap) & 404.40 \\
\hline Tembikai Susu/Melon & Honey Dew & 745.53 \\
\hline Tembikai Wangi & RockMelon & 322.91 \\
\hline JUMLAH & Total & $\mathbf{5 0 1 . 4 9}$ \\
\hline
\end{tabular}

\subsection{Fruit Structure and Physical Properties}

Immature dabai fruit is white, and when ripened, it turns to purplish pink and powdery black. The fruit is oblong, olive-like in form, and have thin, edible skin. The fruit has 20-25 mm wide fleshy and oblong to ellipsoidal drupe, about 35-40 mm long. The dark 
purple skin covers the yellowish-white flesh, and the flesh wraps around the subtriangularshaped seed. A rough shell protects the seed, which can be eaten as a nut (Figure 2). The pulp is between $54-60 \%$ by weight of the fruit and contains $41.3 \%$ of moisture whereas the kernel covers about $35-40 \%$ of the fruit weight (Cangao, 2014).
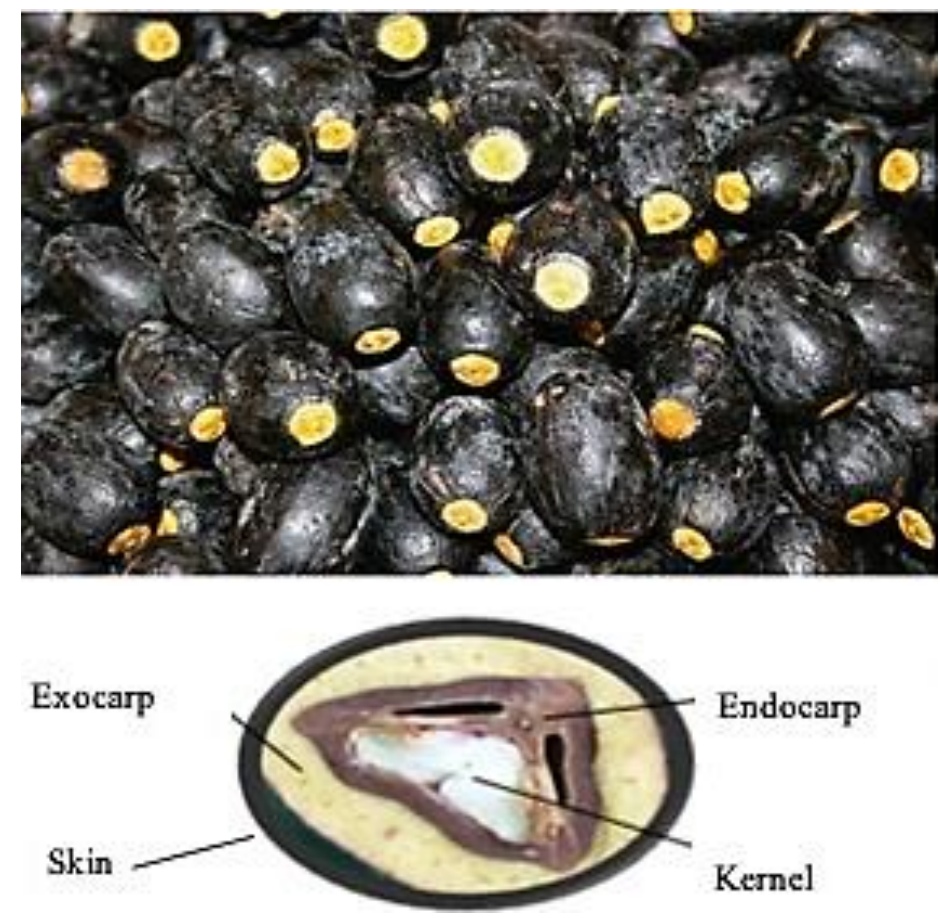

Figure 2. Above, ripe dabai fruit (HealthBenefits, n.d.) and bottom its cross-section (Cangao, 2014).

Study on physical properties of different genotypes of dabai was conducted by (Chua et al., 2015). The information on the physical properties of dabai fruit can be used as baseline information for further processing application, such as appropriate technologies development for processing. In a study reported by Chua et al. (2015), there were six genotypes of dabai fruits which were Besar, Biasa, Jernah, Bujur, Seluang, and Bulat. The size and shape and fruit fraction mass of six dabai fruit genotypes were tabulated in Table 2 and Table 3, respectively. Fruit length $(\mathrm{cm})$, width $(\mathrm{cm})$, and thickness $(\mathrm{cm})$ represent the physical properties of the fruit, sphericity index $(\%)$ and aspect ratio $(\%)$ represent the shape of the fruit. On the other hand, individual weight of whole $(\mathrm{g})$, seed $(\mathrm{g})$, skin $(\mathrm{g})$, pulp $(\mathrm{g})$, and kernel $(\mathrm{g})$ represent the mass of the fruit. 
Table 2. Size and shape of six dabai fruit genotypes $(n=10)$. Table obtained from Chua et al. (2015).

\begin{tabular}{llllll}
\hline & $\begin{array}{l}\text { Fruit } \\
\text { length }(\mathrm{cm})\end{array}$ & $\begin{array}{l}\text { Fruit } \\
\text { width }(\mathrm{cm})\end{array}$ & $\begin{array}{l}\text { Pulp } \\
\text { thickness }(\mathrm{cm})\end{array}$ & $\begin{array}{l}\text { Sphericity } \\
\text { index }(\%)\end{array}$ & $\begin{array}{l}\text { Aspect } \\
\text { ratio }(\%)\end{array}$ \\
\hline Besar & $3.60 \pm 0.15 \mathrm{~b}$ & $2.58 \pm 0.22 \mathrm{a}$ & $0.43 \pm 0.07 \mathrm{a}$ & $42.91 \pm 2.88 \mathrm{~b}$ & $71.57 \pm 5.82 \mathrm{~b}$ \\
Biasa & $3.07 \pm 0.23 \mathrm{c}$ & $2.10 \pm 0.17 \mathrm{c}$ & $0.35 \pm 0.05 \mathrm{~b}$ & $42.46 \pm 1.68 \mathrm{~b}$ & $68.44 \pm 3.88 \mathrm{bc}$ \\
Jernah & $3.00 \pm 0.11 \mathrm{c}$ & $1.94 \pm 0.08 \mathrm{~d}$ & $0.28 \pm 0.03 \mathrm{c}$ & $39.17 \pm 1.49 \mathrm{c}$ & $63.77 \pm 4.60 \mathrm{~cd}$ \\
Bujur & $3.98 \pm 0.20 \mathrm{a}$ & $2.40 \pm 0.13 \mathrm{~b}$ & $0.36 \pm 0.03 \mathrm{~b}$ & $37.73 \pm 0.95 \mathrm{c}$ & $60.38 \pm 3.55 \mathrm{~d}$ \\
Seluang & $2.90 \pm 0.07 \mathrm{c}$ & $1.94 \pm 0.10 \mathrm{~d}$ & $0.22 \pm 0.03 \mathrm{c}$ & $36.97 \pm 1.46 \mathrm{c}$ & $66.89 \pm 3.09 \mathrm{c}$ \\
Bulat & $3.01 \pm 0.14 \mathrm{c}$ & $2.63 \pm 0.15 \mathrm{a}$ & $0.43 \pm 0.03 \mathrm{a}$ & $49.94 \pm 0.90 \mathrm{a}$ & $87.42 \pm 3.75 \mathrm{a}$ \\
\hline
\end{tabular}

Means in the same column with the same letter are not significantly different $(p>0.05)$

Table 3. Fruit fraction mass of six dabai fruit genotypes $(n=10)$. Table obtained from Chua et al. (2015).

\begin{tabular}{|c|c|c|c|c|c|c|}
\hline $\begin{array}{l}\text { Dabai } \\
\text { genotype }\end{array}$ & $\begin{array}{l}\text { Total fruit } \\
\text { mass }(g)\end{array}$ & $\begin{array}{l}\text { Total seed } \\
\text { mass }(\mathrm{g})\end{array}$ & $\begin{array}{l}\text { Skin } \\
\text { mass (g) }\end{array}$ & $\begin{array}{l}\text { Pulp } \\
\text { mass (g) }\end{array}$ & $\begin{array}{l}\text { Kernel } \\
\text { mass (g) }\end{array}$ & $\begin{array}{l}\text { Total edible } \\
\text { portion }(\%)\end{array}$ \\
\hline Besar & $15.33 \pm 1.63 \mathrm{a}$ & $5.84 \pm 0.41 \mathrm{a}$ & $\begin{array}{l}1.45 \pm 0.32 \mathrm{a} \\
(9.46 \%)\end{array}$ & $\begin{array}{l}8.04 \pm 1.28 \mathrm{a} \\
(52.45 \%)\end{array}$ & $\begin{array}{l}1.33 \pm 0.14 a \\
(8.68 \%)\end{array}$ & $70.59 \mathrm{a}$ \\
\hline Biasa & $10.23 \pm 2.07 b$ & $3.83 \pm 0.80 \mathrm{c}$ & $\begin{array}{l}0.78 \pm 0.25 a \\
(7.62 \%)\end{array}$ & $\begin{array}{l}5.62 \pm 1.18 b \\
(54.94 \%)\end{array}$ & $\begin{array}{l}0.94 \pm 0.23 b \\
(9.19 \%)\end{array}$ & $71.75 a$ \\
\hline Jernah & $7.41 \pm 0.68 c$ & $2.83 \pm 0.28 \mathrm{~d}$ & $\begin{array}{l}1.21 \pm 0.20 \mathrm{a} \\
(16.33 \%)\end{array}$ & $\begin{array}{l}3.36 \pm 0.29 c \\
(45.34 \%)\end{array}$ & $\begin{array}{l}0.48 \pm 0.04 \mathrm{~d} \\
(6.48 \%)\end{array}$ & $68.15 b$ \\
\hline Bujur & $15.28 \pm 2.16 a$ & $6.48 \pm 1.02 \mathrm{a}$ & $\begin{array}{l}1.10 \pm 0.19 a \\
(7.20 \%)\end{array}$ & $\begin{array}{l}7.71 \pm 1.20 \mathrm{a} \\
(50.46 \%)\end{array}$ & $\begin{array}{l}1.08 \pm 0.10 \mathrm{~b} \\
(7.07 \%)\end{array}$ & $64.73 c$ \\
\hline Seluang & $7.60 \pm 0.53 c$ & $3.50 \pm 0.25 \mathrm{~cd}$ & $\begin{array}{l}0.85 \pm 0.10 \mathrm{a} \\
(11.18 \%)\end{array}$ & $\begin{array}{l}3.25 \pm 0.33 c \\
(42.76 \%)\end{array}$ & $\begin{array}{l}0.69 \pm 0.08 \mathrm{c} \\
(9.08 \%)\end{array}$ & $63.02 \mathrm{c}$ \\
\hline Bulat & $13.31 \pm 1.10 \mathrm{a}$ & $4.78 \pm 0.34 b$ & $\begin{array}{l}1.11 \pm 0.32 \mathrm{a} \\
(8.34 \%)\end{array}$ & $\begin{array}{l}7.42 \pm 1.13 \mathrm{a} \\
(55.75 \%)\end{array}$ & $\begin{array}{l}0.96 \pm 0.14 b \\
(7.21 \%)\end{array}$ & $71.30 \mathrm{a}$ \\
\hline
\end{tabular}

Means in the same column with the same letter are not significantly different $(p>0.05)$

\subsection{Harvesting and Agronomic Characteristics}

Dabai fruits are ready to be harvested when the immature white fruit turns purplishblack. The fruits are usually harvested in the morning and during dry weather (Lau \& Fatimah, 2007). Usually, a sickle is attached to the end of a long bamboo pole to cut the terminal branches of the fruit panicles. A net is located under the tree to collect the falling fruits and branches. Fruits are removed manually from their pedicels and transported to the market in well-ventilated baskets (Ding, 2011).

There are three development stages of dabai fruit which are immature, semi-mature, and mature (Figure 3). The maturity development stages were reported to have effects on the physical and nutritional values of dabai fruit. The colour of dabai fruit changes from white to reddish-black-white, and purplish-black during the three development stages, with fat 
content, increased from $15.8 \%$ to $24.6 \%$ and $27.6 \%$ during immature, semi-mature, and mature stage respectively. On the other hand, fibre content was found to decrease from $22.1 \%$ to $17.9 \%$ and $14.6 \%$ whereas protein also decreased from $10.8 \%$ to $9.8 \%$, and $9.2 \%$ from immature to mature stage. The carbohydrate was found to be almost similar throughout the stages $(43.7 \%, 40.9 \%$, and $42.5 \%)$ while the moisture content was found to decrease by $11 \%$ from immature to mature stage (Yuon \& Brooke, 2006).

It has been reported that fat, fibre, protein and carbohydrate contents of the mature fruit change while they are retained on the tree for two months. Thus, it has been suggested that the best time to harvest dabai is about two (2) weeks after full maturity when the fruits are at their optimal physical appearance while at the same time having favourable fat and protein contents (Yuon \& Brooke, 2006).

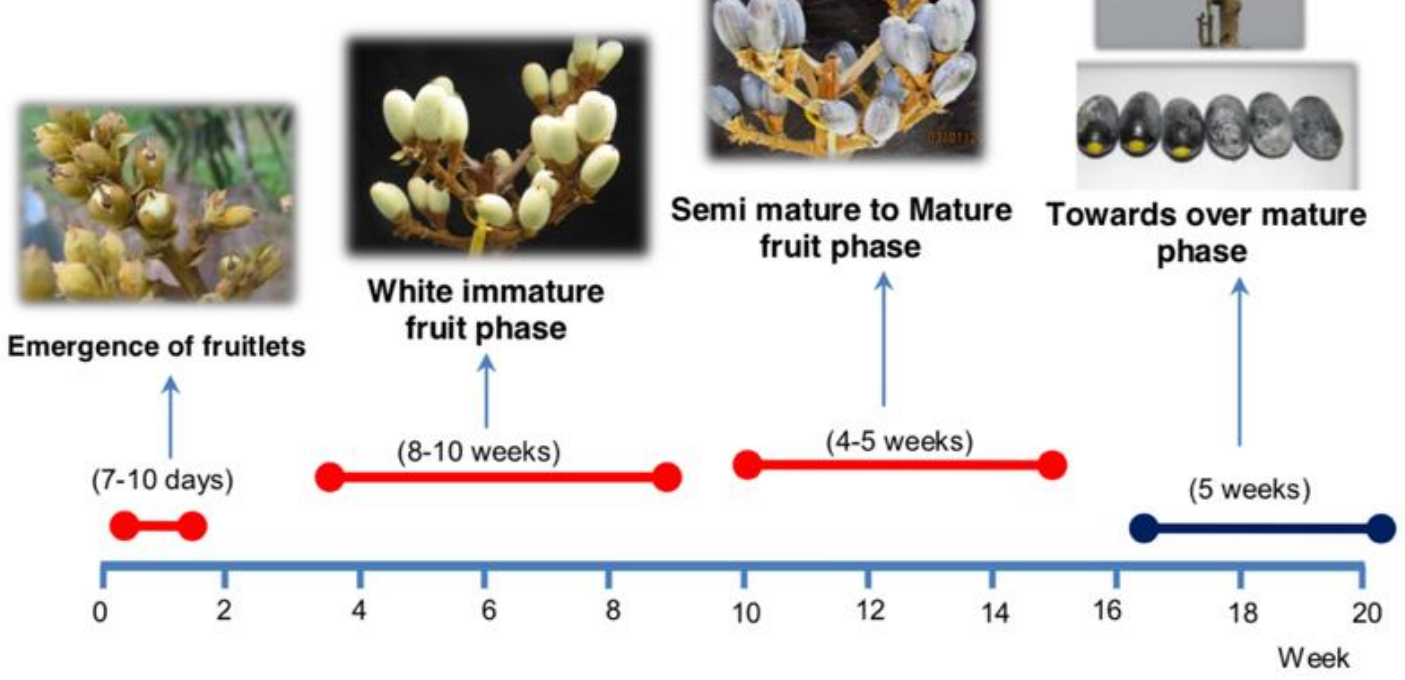

Figure 3. Timeline chart of dabai fruit during maturation process. Image taken from (Yuon \& Brooke, 2006).

\subsection{Health Benefits and Nutritional Values}

Dabai fruit is highly beneficial for health. It acts as an antioxidant that helps in preserving the skin from ageing and protecting skin from sun damage. The calcium content promotes bone mass in grown children as well as young adults. The magnesium could be very beneficial to the cardiovascular system by reducing the risk of coronary heart diseases. The lipid content helps to produce energy and providing support for vital organs. The 
anthocyanin aids as an anti-inflammatory, and the phenolic compounds could help in cancer prevention and act as antioxidants (Dezatie, 2013). Example of nutritional values found in dabai is tabulated in Table 4.

The fresh pulp of dabai (for $100 \mathrm{~g}$ ) contains $339 \mathrm{kcal}$ energy, $22.1 \mathrm{~g}$ carbohydrates, $4.3 \mathrm{~g}$ crude fibre, $3.8 \mathrm{~g}$ protein, $2.3 \mathrm{~g}$ ash, and $26.2 \mathrm{~g}$ fat. Dabai oil produced from the pulp has comparable nutrient content with $40 \%$ saturated and monounsaturated fatty acids and $12-$ $13 \%$ polyunsaturated fatty acids. The kernel contains $499.36 \mathrm{kcal}$ energy, $47.24 \mathrm{~g}$ carbohydrates, 15.80 crude fibre, 10.75 protein, $3.35 \mathrm{~g}$ ash, and $26.20 \mathrm{~g}$ fat (Cangao, 2014). The dark purple skin was found to have the highest antioxidant activity at $89.31 \%$ (Cangao, 2014).

Potential healthy cooking oils could be developed from pulp and kernel oils of dabai due to their good fatty acid composition and high antioxidant properties (Azlan et al., 2010). As for the peel, it was recommended to be a major source of natural antioxidants (Shakirin et al., 2010). Apart from that, there was also a study reported on the potential use of defatted dabai peel on future nutraceuticals line (Khoo et al., 2013). The study showed that the highest antioxidant capacities and oxidative stress inhibition effect were found in defatted dabai peel. The defatted dabai peel elevates cellular antioxidant enzymes (SOD and GPx) and inhibits lipid peroxidation (plasma MDA) in rabbits (Khoo et al., 2013). Most significant antioxidant activities with highest anthocyanin, flavonoids and total phenolic contents were found in purple dabai from Kapit $(p<0.01)$ (Chew et al., 2011).

Table 4. Nutritional values of dabai fruit. Data obtained from Hoe and Siong (1999).

\begin{tabular}{|l|l|}
\hline \multicolumn{1}{|c|}{ Nutritional aspect } & \multicolumn{1}{c|}{ Nutritional value } \\
\hline Energy & $339 \mathrm{kcal} 100 \mathrm{~g}-1$ edible portion \\
\hline Phosphorus & $65 \mathrm{mg} 100 \mathrm{~g}-1$ edible portion \\
\hline Ferum & $1.3 \mathrm{mg} 100 \mathrm{~g}-1$ edible portion \\
\hline Potassium & $810 \mathrm{mg} 100 \mathrm{~g}-1$ edible portion \\
\hline Magnesium & $106 \mathrm{mg} 100 \mathrm{~g}-1$ edible portion \\
\hline Calcium & $200 \mathrm{mg} 100 \mathrm{~g}-1$ edible portion \\
\hline Protein & $3.8 \%$ \\
\hline Carbohydrate & $22.1 \%$ \\
\hline Ash & $2.3 \%$ \\
\hline Crude fibre & $4.3 \%$ \\
\hline Fat & $26.2 \%$ \\
\hline
\end{tabular}




\section{Postharvest Handling}

Regardless of its hard texture, dabai is a highly perishable fruit. The shelf life of dabai is usually 3 days when stored in room temperature $\left(27^{\circ} \mathrm{C}\right)$ (Ding, 2011). After that, the fruit will still be edible, but the skin of the hard fruit will wrinkle. The short shelf life of dabai fruit resulted in limitation for potential marketing. Usually, the fruit is marketed locally or exported to nearby towns in Sabah and Brunei. Due to this restricted market, dabai price tends to crash due to the over-supply of the fruit during peak crop seasons (Ding, 2011). It has been reported that by packing the fruit in polyethene bags, the shelf life of dabai could be prolonged up to 8 days when stored at $14^{\circ} \mathrm{C}$ (Jugah, 2006). A study also claimed that the shelf life of dabai could be prolonged when stored at $5^{\circ} \mathrm{C}$ and water loss could be minimised by coating the fruit with thin layer of edible oil (Voon, 2003). In other study, dabai fruit was vacuum-packed and frozen for 6 months and the frozen fruits were thawed by using hot water at $100^{\circ} \mathrm{C}$ instead of warm water. Although the fruit is still acceptable, freezing has affected the taste and appearance by resulting in less creamy taste and poorer physical appearance (Lau \& Fatimah, 2007).

Usually, in the market, people put dabai fruit in a big-open box and ready for a sale (Figure 4). The high surrounding temperature $\left(27-30^{\circ} \mathrm{C}\right)$ and open gaseous exchange between these highly perishable fruits and the surrounding air lead to the short shelf life of dabai fruit (Ding \& Tee, 2011). Further studies are still necessary to find the best storage and packaging conditions that could help to maintain the quality and extend the shelf life of dabai fruit, thus open the opportunity for greater market scale and export potential.

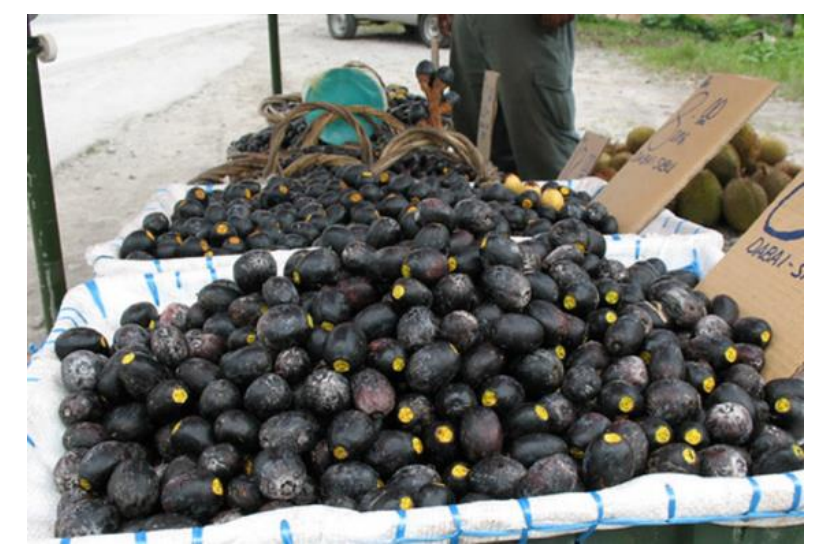

Figure 4. Dabai for sale at the roadside. Image taken from Bingregory (2007). 


\section{Dabai Fruit in Food and Health Products}

Traditionally, dabai is prepared by immersing the fruit in lukewarm water for 15 minutes to soften the fruit. This step will enhance the smooth-creamy texture and rich flavour of the fruit (Ding, 2011). The flesh of dabai fruit is enjoyed with the skin while the hard seed is removed. It is then eaten with sugar and/or soy sauce to enhance the taste of the fruit. It can be enjoyed as part of a meal or as a savoury snack. Sauce made from dabai fruit has also been introduced and found to be acceptable among consumers (Nazri et al., 2015) and this shows potential innovation of dabai for food product development. Various food products have been developed to maintain a continuous supply of dabai during the off-season. Some examples of the food products are dabai pickles, mayonnaise, seasoning paste, dipping sauce, drinks, and frozen pulp (Chua \& Daniel, 2017).

Good quality of fat was extracted from dabai. Oleic (18:1), linoleic (18:2) and palmitic (16:0) acids are the most abundant fatty acids in the fruit, and the percentage is found comparable to palm oil (Azlan et al., 2010). Pulp and kernel oils from dabai have been tested to study the effects of oxidative stress, lipid profile, and lipid peroxidation on healthy rabbits. The kernel oil enhanced superoxide dismutase (SOD) and total antioxidant status (TAS) and reduced plasma total cholesterol (TC) and low-density lipoprotein cholesterol (LDL-C) levels. The pulp oil enhanced SOD, glutathione peroxidase (GPX) and plasma TAS, increased HDL-C, and reduced LDL-C, TG, and thiobarbituric acid reactive substances (TBARS) levels. Considering the use of kernel and pulp oils as part of a diet could be beneficial in improving antioxidant and lipid profile (Shakirin et al., 2012). This study shows the potential use of oils extracted from dabai fruit to be the alternative to present vegetable oil.

In the medical fields, dabai fruit extract was tested on obese-diabetic (Ob-db) rats, and it was found that the extract improves lipid profile and has a short-term glucose-lowering effect (Mokiran et al., 2014). The fruit extract was able to reduce plasma cholesterol and lowdensity lipoprotein (LDL-c) and plasma glucose level while at the same time increased highdensity lipoprotein (HDL-c) level (Mokiran et al., 2014). It could be a potential alternative in treating obese patients.

\section{Conclusion}

Dabai is a highly nutritious fruit that has a potential and promising market value. Improper handling of dabai fruit leads to quality and shelf life reduction. Proper handling and packaging of the fruit are necessary in order to maintain the quality and extend the shelf life 
of the fruit. There is still a limitation on the information of the postharvest, storage and handling, quality and shelf life on dabai fruit. Further works that cover quality and shelf life such as the effect of storage treatment and packaging on dabai is necessary to study the respiration rate of dabai fruit thus optimising shelf life and minimising quality loss of the fruit. It could ensure further development of the fruit locally and internationally. Kinetic degradation and mathematical modelling could also be implemented to predict the quality and shelf life of the fruit on a large scale. Valued food product innovations also could be further developed to utilise the use of the fruit during the off-season.

Supplementary Materials: The following are available online at http://www.journals.hhpublisher.com/index.php/AAFRJ//xxx/s1, Figure 1, Figure 2, Figure 3, Figure 4-SHA, List of Tables_SHA

Funding: The authors would like to thank the Ministry of Higher Education of Malaysia, for providing financial support under the Fundamental Research Grants Scheme (FRGS) (Project Number: FRGS/1/2019/WAB01/UPM/02/03) and the Sarawak Biodiversity Centre.

Conflicts of Interest: The authors declare no conflict of interest, and also the funders had no role in the design of the study; in the collection, analyses, or interpretation of data; in the writing of the manuscript, or in the decision to publish the results.

\section{References}

Azlan, A., Prasad, K. N., Khoo, H. E., et al. (2010). Comparison of fatty acids, vitamin E and physicochemical properties of Canarium odontophyllum Miq. (dabai), olive and palm oils. Journal of Food Composition and Analysis, 23(8), 772-776. https://doi.org/10.1016/j.jfca.2010.03.026

Bingregory. (2007). Dabai for Sale at the Roadside. Retrieved October 10, 2019, from https://www.flickr.com/photos/21227234@N00/364543169/in/photostream/

Cangao, C. A. (2014). The dabai story: Experience in commercializing an underutilized fruit. Retrived from https://www.itfnet.org/v1/2014/03/the-dabai-story-experience-in-commercializing-an-underutilizedfruit/

Chew, L. Y., Prasad, K. N., Amin, I., et al. (2011). Nutritional composition and antioxidant properties of Canarium odontophyllum Miq. (dabai) fruits. Journal of Food Composition and Analysis, 24(4-5), 670677. https://doi.org/10.1016/j.jfca.2011.01.006

Chua, H. P., Nicholas, D., \& Yahya, M. N. A. (2015). Physical properties and nutritional values of dabai fruit (Canarium odontophyllum) of different genotypes. Journal of Tropical Agriculture and Food Science, 43(1), 1-10. https://doi.org/10.13140/2.1.2944.3366

Chua, H. P., \& Daniel, N. (2017). Dabai, specialty fruit of Sarawak. Retrieved from https://blogmardi.wordpress.com/2017/02/13/dabai-specialty-fruit-of-sarawak/ 
Department of Agriculture Malaysia.

(2017). Statistik Tanaman Buah-Buahan Malaysia. Putrajaya, Malaysia.

Dezatie. (2013). Dabai fruit and its contains. Retrieved from http://dezatiee.blogspot.com/2013/12/dabai-fruitand-its-contains.html

Ding, P. (2011). Dabai (Canarium odontophyllum Miq.). Postharvest biology and technology of tropical and subtropical fruits (34-42) Woodhead Publishing Limited. https://doi.org/10.1016/B978-1-84569-735$8.50003-6$

Ding, P., \& Tee, Y. K. (2011). Physicochemical characteristics of dabai (Canarium odontophyllum Miq.) fruit. Fruits, 66(1), 47-52. https://doi.org/10.1051/fruits/2010040

HealthBenefits. (n.d.). Know About the Dabai. Retrieved May 16, 2020, from https://www.healthbenefitstimes.com/know-about-the-dabai/nggallery/image/12773

Hoe, V. B., \& Siong, H. . (1999). The nutritional value of indigenous fruits and vegetables in Sarawak. Asia Pacific Journal of Clinical Nutrition, 8, 24-31.

Jugah D. J. (2006). Study on the effect of packaging and temperature on improving the shelf life of dabai (Canarium odontophyllum). In Proceedings of Technical Session, Research Officers' Conference 2006, 7-9 September 2006, Kuching, Sarawak, Malaysia.

Khoo, H. E., Azlan, A., Nurulhuda, M. H., et al. (2013). Antioxidative and cardioprotective properties of anthocyanins from defatted Dabai extracts. Evidence-Based Complementary and Alternative Medicine, 2013, 1-13. https://doi.org/10.1155/2013/434057

Lau C. Y. \& Fatimah O. (2007). Cold storage of dabai fruit (Canarium odontophyllum Mig.): Effect of packaging methods and storage duration on quality. In Proceedings of the Sarawak Fruit Seminar, 7-8 August 2007, Sibu, Sarawak, Malaysia.

Mokiran, N. N., Ismail, A., Azlan, A., et al. (2014). Effect of dabai (Canarium odontophyllum) fruit extract on biochemical parameters of induced obese-diabetic rats. Journal of Functional Foods, 8(1), 139-149. https://doi.org/10.1016/j.jff.2014.03.007

Nazri, M., Rahman, A., Azimah, N., et al. (2015). Product development of kembayau (Canarium odontophyllum) exotic fruit sauce. Journal of Tropical Resources and Sustainable Science, 3(1), 19-28.

Shakirin, F. H., Azlan, A., Ismail, A., et al. (2012). Protective effect of pulp oil extracted from Canarium odontophyllum Miq. fruit on blood lipids, lipid peroxidation, and antioxidant status in healthy rabbits. Oxidative Medicine and Cellular Longevity, 2012, (1-9). https://doi.org/10.1155/2012/840973

Shakirin, F. H., Prasad, K. N., Ismail, A., et al. (2010). Antioxidant capacity of underutilized Malaysian 
Canarium odontophyllum (dabai) Miq. fruit. Journal of Food Composition and Analysis, 23(8), 777-781. https://doi.org/10.1016/j.jfca.2010.04.008

Voon B. H. (2003). Indigenous fruits for commercial exploitation. In Proceedings of In-house Seminar on New Crops with Potential for Commercialization, 7-8 August 2003, Sg. Paoh Agriculture Training Centre, Sarikei, Sarawak, Malaysia.

Yuon, L. C., \& Brooke, P. (2006). Changes to dabai fruit during maturation process. Agriculture Research Centre, Semongok, Sarawak, Malaysia. 